\title{
MEME DAN VISUALISASI KEBENCIAN NETIZEN DALAM KASUS PENISTAAN AGAMA
}

\author{
Abdul Malik \\ Dosen Program Studi Ilmu Komunikasi Universitas Serang Raya \\ Jalan Raya Cilegon-Serang Km. 5, Drangong, Serang, Banten \\ No. HP.:087771791880,E-mail: kangdoel2002@gmail.com
}

\begin{abstract}
Abstrak
Kasus dugaan penistaan agama yang dilakukan Basuki Tjahaja Purnama alias Ahok tidak hanya menimbulkan pro dan kontra di masyarakat, tetapi juga polemik di dunia maya. Media sosial seperti Facebook dipenuhi berbagai wacana kebencian. Banyak netizen memproduksi dan mereproduksi meme untuk memvisualisasikan kebenciannya terhadap pihak-pihak yang terkait dengan kasus tersebut. Tulisan ini mengkaji bagaimana netizen mengekspresikan kebenciannya terhadap pihak-pihak yang terkait dengan kasus dugaan penistaan agama melalui visualisasi meme, dan bagaimana penggambaran netizen terhadap pihak-pihak yang menjadi objek visualisasi dalam bentuk meme tersebut. Hasilnya, berbagai penggambaran netizen kepada para pihak terkait kasus dugaan penistaan agama mengerucut kepada bentuk kebencian dan pembelaan. Netizen yang kontra memvisualisasikan Ahok sebagai penista agama, tidak layak menjadi pemimpin, dan berbagai visualisasi kebencian lain. Kelompok pro-Ahok, Megawati Soekarnoputri, Kapolri Jenderal Polisi Tito Karnavian, dan Presiden Jokowi, juga menjadi pihak yang tidak luput dari penggambaran negatif penuh kebencian. Di sisi lain, meme terhadap Buni Yani memberikan penggambaran positif. Ia menjadi sosok yang dibela. Netizen pro-Ahok memberikan penggambaran berisi pembelaan terhadap Ahok tetapi bertendensi kebencian terhadap kelompok kontra-Ahok. Gambaran kebencian juga dilakukan oleh netizen terhadap Buni Yani, kelompok kontra-Ahok, dan terutama sekali terhadap Habib Rizieq.
\end{abstract}

Kata kunci: meme, visualisasi kebencian, penistaan agama

\begin{abstract}
Meme and Visualization of Netizen's Hatred in the Case of Blasphemy. Cases of alleged blasphemy committed Basuki Tjahaja Purnama (Ahok) not only raises the pros and cons in the community but also polemic in cyberspace. Social media such as Facebook is full of hatred discourse. Many netizens produce and reproduce meme to visualize the hatred of the parties associated with the case. This article examines how netizens express their hatred against those associated with cases of alleged blasphemy through visualization of meme and how the netizens depict those parties associated as the object of visualization in the form of meme. As the result, many depictions from the netizens towards the parties related to the alleged blasphemy taper to hatred and defense. Those who are in cons visualize Ahok as a blasphemer, unfit to be a leader, and a variety of other hatred visualizations. While those in pros, Megawati Sukarnoputri, Chief of National Police Tito Karnavian, and President Jokowi, also become parties who cannot escape from negative depiction of hatred. On the other side, the meme towards Buni Yani give positive portrayals. He becomes the person who is defended. Netizens who are pro-Ahok give depiction of their defense for Ahok but showing tendencies of hatred toward the cons. Depiction of hatred is also done by netizens towards Buni Yani, counterAhok, and particularly towards Habib Rizieq.
\end{abstract}

Keywords: meme, hatred visualization, blasphemy 


\section{PENDAHULUAN}

Setiap hari muncul terpaan beragam informasi, baik bersumberkan media cetak, elektronik, maupun internet. Berbagai jenis informasi itu datang silih berganti melintasi batas ruang dan waktu. Terlebih dengan kehadiran media jenis baru berbasis internet, akses untuk memperoleh informasi menjadi semakin mudah dan murah sehingga dari waktu ke waktu manusia tidak lagi bisa lepas dari informasi. Kenyataan ini menunjukkan bahwa media massa saat ini telah benar-benar merasuk (pervasive) ke dalam ruang kehidupan sehari-hari.

Di sisi yang lain, kehadiran internet (cyberspace) dalam satu dekade ini telah melahirkan berbagai optimisme masa depan dalam bentuk berbagai kemudahan sosialisasi wacana kehidupan sosial, politik, ekonomi, pendidikan, dan kebudayaan. Di dalam wacana politik, khususnya, internet telah memberikan optimisme dalam kedudukannya sebagai 'kekuatan baru', yang dapat menciptakan iklim demokrasi yang lebih kondusif. Internet, sebagai salah satu elemen utama cyberspace, dianggap sebagai saluran komunikasi yang memiliki jangkauan komunikasi terluas dan diharapkan menjadi ruang publik baru yang ideal, yakni ruang publik cyber, di mana di dalamnya bertemu berbagai pihak yang saling berkomunikasi satu sama lain secara bebas (Sutrisno, n.d.)

Kendati demikian, harapan bahwa internet dapat menjadi sarana untuk menciptakan iklim demokrasi yang kondusif itu tidak pernah benarbenar terjadi. Kenyataan tersebut sesuai dengan apa yang dikemukakan oleh (Vivian, 2008) bahwa keberadaan internet sebagai media massa yang demokratis dikarenakan banyak orang yang dapat menciptakan isinya sendiri-sendiri, tidak terlepas dari kelemahan. Kelemahan itu adalah ketiadaan gatekeeper sebagaimana di media tradisional sehingga konten ataupun isi pesannya tidak terjamin tingkat akurasinya. Disebabkan ketiadaan gatekeeper itulah, internet penuh dengan informasi sampah.

Karena ketiadaan gatekeeper itulah, media internet utamanya media sosial kerap dipenuhi oleh berbagai wacana yang justru tidak mencerminkan semangat demokratisasi sebagaimana diharapkan. Kenyataan tersebut setidaknya terlihat dari pemanfaatan media sosial Facebook oleh para netizen yang belakangan cenderung bebas tanpa batas dan dan lebih dominan dimanfaatkan sebagai ajang untuk membangun dan menyebarkan pesan maupun wacana-wacana kebencian dalam berbagai bentuk dan rupa. Dugaan penistaan agama oleh Basuki Tjahaja Purnama alias Ahok adalah contoh kasus yang mendapatkan perhatian luar biasa di kalangan netizen dengan wacana-wacana yang terbangun di dalamnya penuh dengan nuansa kebencian. Baik kebencian terhadap agama, ras, golongan, termasuk kebencian terhadap simbol-simbol negara.

Seperti diwartakan oleh media online BBC Indonesia (Bbc.com, 2017) polemik tentang kasus dugaan penistaan agama ini berawal saat berlangsung dialog antara Ahok dengan warga di Kepulauan Seribu pada 27 September 2016. Dalam dialognya Ahok sempat melontarkan pencalonannya kembali sebagai gubernur dalam Pilkada DKI 2017 dan memberikan kebebasan kepada masyarakat untuk memilih siapa pun calon gubernurnya seraya menyinggung tentang surat al-Maidah ayat 51 .

Ungkapan Ahok menjadi polemik setelah videonya di-edit dan di-posting oleh seorang bernama Buni Yani. Ia mengedit isi video tersebut dengan menghilangkan kata-kata 'pakai' dari "Karena dibohongin pakai surat al-Maidah 51...." menjadi "Karena dibohongin Surat al-Maidah 51...." dan mem-posting-ya di akun Facebook miliknya.

Pasca itulah pernyataan Ahok menjadi viral di Facebook karena terus di-share oleh para netizen hingga menimbulkan pro-kontra dan kegaduhan yang 
luar biasa di ruang maya. Berbagai komentar atau tautan informasi/berita terkait kasus tersebut muncul di banyak akun baik pribadi maupun grup, berisi wacana-wacana kebencian karena sifatnya yang saling serang atau saling dukung terhadap para pihak yang terlibat dalam persoalan tersebut. Pesan dan wacana kebencian itu datang silih berganti tanpa henti karena terus diproduksi dan direproduksi dengan cara di-share kepada sebanyak-banyaknya netizen, lalu dikomentari dengan penuh kebencian pula.

Selain dalam bentuk teks berupa komentar atau tulisan, pesan dan wacana kebencian juga divisualisasikan melalui gambar atau foto yang telah direkayasa menjadi meme. Ada yang bersifat karikatif, namun tetapi tidak sedikit yang bersifat sarkastik dan mengandung kebencian begitu rupa terhadap pihak yang menjadi objek visualisasi tersebut. Dalam hal ini, meme sebagai sebuah kreativitas berbasis reka cipta foto atau gambar yang dibubuhi dengan kata atau kalimat tertentu telah dijadikan oleh netizen untuk mengekspresikan kebenciannya terhadap pihak-pihak tertentu melalui aneka visualisasi dengan maksud memberikan penggambaran sesuai dengan kehendak pembuatnya.

Dalam perspektif komunikasi, visualisasi kebencian oleh netizen dalam meme terkait kasus dugaan penistaan agama adalah bentuk dari komunikasi visual, yaitu netizen memproduksi pesan-pesan tertentu yang divisualisasi, baik dalam wujud foto atau gambar, atau paduan foto dan gambar dengan kata atau kalimat yang menggambarkan pihak yang menjadi objek visualisasi. Komunikasi visual ini bersifat ekspresif karena disampaikan melalui pesan-pesan nonverbal dan bertujuan untuk menyampaikan perasaan dan sikap netizen terkait dengan kasus dugaan penistaan agama. Dalam hal ini Davison dalam Nasrullah (2016) menyatakan bahwa an internet meme is a piece of culture, typically a joke, which gains influence through online transmission. Meme adalah bagian dari budaya -- kadang sebuah lelucon - yang muncul dan ditransmisikan melalui internet. Meme bukanlah sekadar lelucon, melainkan cerminan dari realitas offline yang disajikan dengan visual yang menarik.

Dalam perspektif konstruktivis, meme tentang visualisasi kebencian yang diproduksi dan direproduksi oleh netizen adalah hasil dari konstruksi mereka terhadap realita yang terjadi. Realita tersebut diobjektivikasi, lalu diinternalisasi dalam ruang pikir dan ruang batin netizen, kemudian dieksternalisasi dalam bentuk meme dengan ragam visualisasi.

Sehubungan dengan persoalan tersebut, tulisan ini mengkaji bagaimana netizen mengekspresikan kebenciannya terhadap pihakpihak yang terkait dengan kasus dugaan penistaan agama melalui visualisasi meme dan bagaimana penggambaran netizen terhadap pihak-pihak yang menjadi objek visualisasi dalam bentuk meme tersebut?

\section{LANDASAN TEORI}

\section{Komunikasi Visual}

Komunikasi dalam kehidupan manusia bersifat serba hadir. Karena itu, dimensi komunikasi sangatlah luas. Komunikasi tidak hanya bersifat verbal, tetapi juga bersifat nonverbal. Adapun komunikasi visual adalah bentuk dari komunikasi nonverbal. Komunikasi visual merupakan suatu bentuk kebutuhan manusia dalam mendapatkan informasi melalui visualisasi yang dikemas secara menarik (Tinarbuko, 2003).

Secara lebih spesifik komunikasi visual merupakan konsep komunikasi dan ungkapan daya kreatif yang diaplikasikan dalam berbagai media komunikasi visual. Melalui visualisasi tersebut pesan diproduksi sekaligus direproduksi untuk memperoleh respons dari pihak lain. Umar Hadi dalam Tinarbuko (2003) mengatakan bahwa sebagai bahasa, desain komunikasi visual adalah ungkapan 
ide, dan pesan dari perancang kepada publik yang dituju melalui simbol berujud gambar, warna, tulisan, dan lainnya. Ia akan komunikatif apabila bahasa yang disampaikan itu dapat dimengerti oleh publik. Komunikasi visual juga akan berkesan apabila dalam penyajiannya itu terdapat suatu kekhasan atau keunikan sehingga ia tampil secara istimewa, mudah dibedakan dengan yang lain. Maka dalam berkomunikasi, diperlukan sejumlah pengetahuan yang memadai seputar siapa publik yang dituju, dan bagaimana cara sebaik-baiknya berkomunikasi dengan mereka.

Seiring dengan perkembangan teknologi komunikasi yang semakin canggih, saat ini komunikasi visual semakin mudah dilakukan. Tidak hanya oleh orang-orang profesional untuk memproduksi iklan atau media luar ruang, tetapi juga bisa dilakukan oleh siapa saja untuk memproduksi dan mereproduksi aneka pesan yang divisualisasi, termasuk dalam hal ini meme internet. Di sisi lain, berbagai teknik untuk melakukan reka cipta atau reka bentuk foto atau gambar dalam bentuk digital juga kian mempermudah siapa pun untuk melakukan komunikasi secara visual.

Dibandingkan dengan bentuk komunikasi yang lain, komunikasi visual memiliki keunggulan terutama dalam hal bagaimana pesan-pesan yang ingin disampaikan tervisualisasi dengan jelas, baik melalui gambar, warna, maupun aneka tanda dan simbol yang menyertainya. Dengan demikian, siapa pun dapat dengan mudah memahami maksud dan tujuan dari dibuatnya pesan-pesan yang divisualisasi tersebut.

\section{Meme sebagai Bentuk Komunikasi Ekspresif}

Istilah meme berasal dari bahasa Yunani "mimema", artinya sesuatu yang menyerupai/ menirukan, dan terdengar serupa dengan gen (gene). Dikemukakan kali pertama oleh Richard Dawkins untuk mendefinisikan lahirnya budaya dengan anggapan terjadinya merupakan bentukan dari banyak replikator (penyerupaan). Berdasarkan teorinya itu Dawkins menyatakan bahwa manusia seharusnya melihat kelahiran budaya berasal dari banyaknya bentukan replikator, yang umumnya menyerupai melalui hubungan dengan manusia lain yang telah berevolusi, baik sebagai peniru informasi maupun perilaku yang efisien. Singkatnya, manusia membentuk budaya baru dari terjemahan atas budaya lain yang dialaminya terlebih dahulu.

Istilah meme (seperti dikutip dari Solopos. com, 2017), menjadi terkenal setelah muncul meme internet, sebuah ilustrasi kreatif untuk menggambarkan situasi tertentu. Meme dalam internet juga didasarkan pada istilah mimema dalam bahasa Yunani ini. Ketika diadaptasi dalam bahasa Inggris, mimema, sama artinya dengan imitation atau tiruan jika diterjemahkan dalam bahasa Indonesia. Karen Schubert dalam bukunya Bazar Goes Bizzare yang terbit 2003 seperti ditutis USA Today, Juni 2007, menguraikan meme sebagai sesuatu yang menjadi terkenal melalui internet, seperti gambar, video, atau bahkan orang. Mimema internet biasanya tercipta saat seseorang membuat atau mengunggah sesuatu di internet, dan menyebar secara luas.

Selain Karen, Garry Marshall dari School of Computing Science, Middlesex University, juga pernah meneliti tentang meme. Dalam uraiannya berjudul The Internet and Memetics Garry menjelaskan bahwa budaya pop internet telah menciptakan gaya komunikasi baru. Uraian Garry bersumber dari artikel Francis Heylighen berjudul Evolution of Memes on the Network: From Chain-Letters to the Global Brain. Uraian ini sering menjadi rujukan peneliti komunikasi internet dan meme.

Dalam perkembangannya, meme menjadi istilah spesifik untuk media visual berupa gambar 
ilustrasi. Meme menjadi istilah yang melekat pada gambar olahan kreatif. Perbedaan paling mencolok lainnya terlihat dari fungsi meme yang belakangan berkembang menjadi ilustrasi bergaya parodi, yaitu meme biasa menirukan objek yang dituju dengan gaya dipelesetkan. Meme juga acapkali diolah dengan gaya satire dan cenderung tajam. Katakata vulgar juga muncul pada meme tertentu. Hal ini sesuai dengan yang dikemukakan Davison dalam Nasrullah (2016) bahwa an internet meme is a piece of culture, typically a joke, which gains influence through online transmission. Meme adalah bagian dari budaya -- kadang sebuah lelucon - yang muncul dan ditransmisikan melalui internet. Meme bukanlah sekadar lelucon, melainkan cerminan dari realitas offline yang disajikan dengan visual yang menarik

Situs (Jurnalweb.com, 2017) menyebut bahwa di Indonesia meme internet mengalami lonjakan volume pada saat Pemilu Presiden tahun 2014 lalu, begitu banyak meme tentang Jokowi dan Prabowo yang beredar di internet pada saat itu. Belakangan, seiring dengan polemik tentang kasus dugaan penistaan agama oleh Basuki Tjahaja Purnama, juga banyak bermunculan berbagai meme yang diproduksi dan direproduksi netizen.

Dalam perspektif komunikasi, meme internet adalah bentuk dari komunikasi visual, yaitu netizen memproduksi pesan-pesan tertentu yang divisualisasi, baik dalam wujud foto maupun gambar, atau paduan foto dan gambar dengan kata atau kalimat yang menggambarkan pihak yang menjadi objek visualisasi. Komunikasi visual ini bersifat ekspresif karena disampaikan melalui pesan-pesan nonverbal dan bertujuan untuk menyampaikan perasaan dan sikap netizen terkait dengan persoalan yang menjadi perhatiannya. Hal ini sesuai dengan tujuan dari komunikasi ekspresif itu sendiri. Dalam hal ini Mulyana (2003) menyebut bahwa komunikasi ekspresif tidak otomatis bertujuan memengaruhi orang lain, namun dapat dilakukan sejauh komunikasi tersebut menjadi instrumen untuk menyampaikan perasaan-perasaan (emosi). Perasaan-perasaan tersebut terutama dikomunikasikan melalui pesan-pesan nonverbal, baik melalui gesture, puisi, musik, lukisan, maupun gambar.

\section{Konstruksi Sosial}

Istilah konstruksi sosial atas realitas (sosial construction of reality) didefinisikan sebagai proses sosial melalui tindakan dan interaksi di mana individu menciptakan secara terus-menerus suatu realitas yang dimiliki dan dialami bersama secara subjektif (Poloma, 2004). Teori yang dicetuskan oleh (Berger \& Luckman, 2012) ini bertujuan untuk menjelaskan kenyataan yang terjadi dalam sebuah masyarakat.

Inti dari teori ini adalah individu karena individu dilihat sebagai seorang "aktor" kreatif dari lingkungan sosialnya. Jadi, realitas yang terjadi pada sebuah masyarakat merupakan bentukan atau hasil pemikiran dari individu dalam masyarakat itu sendiri. Hal inilah yang disebut sebagai konstruksi sosial. Dalam teorinya ini, Berger \& Luckman (2012) menaruh perhatian pada kajian tentang hubungan antara pemikiran manusia dan konteks sosial di mana pikiran tersebut ada, berkembang, dan dilembagakan.

Berikut adalah beberapa asumsi dasar dari Teori Konstruksi Sosial (Berger \& Luckman, 2012):

a. Realitas merupakan hasil ciptaan manusia kreatif melalui kekuataan konstruksi sosial terhadap dunia sosial di sekelilingnya.

b. Hubungan antara pemikiran manusia dan konteks sosial tempat pemikiran itu timbul, bersifat berkembang dan dilembagakan.

c. Kehidupan masyarakat itu dikonstruksi secara terus-menerus.

d. Membedakan antara realitas dengan pengetahuan. Realitas diartikan sebagai kualitas 
yang terdapat di dalam kenyataan yang diakui sebagai memiliki keberadaan (being) yang tidak bergantung kepada kehendak kita sendiri. Sementara pengetahuan didefinisikan sebagai kepastian bahwa realitas-realitas itu nyata (real) dan memiliki karakteristik yang spesifik.

Bagi Berger \& Luckman (2012), masyarakat merupakan fenomena dialektis dalam pengertian bahwa masyarakat adalah suatu produk manusia yang akan selalu memberi tindak balik kepada produsennya. Masyarakat tidak memiliki bentuk lain kecuali untuk yang diberikan padanya oleh aktivitas dan kesadaran manusia. Setiap masyarakat manusia adalah suatu usaha pembangunan dunia. Proses dialektik fundamental dari masyarakat terdiri dari tiga momentum atau langkah, yaitu eksternalisasi, objektivasi, dan internalisasi.

Eksternalisasi adalah suatu pencurahan kedirian manusia secara terus-menerus ke dalam dunia, baik dalam aktivitas fisik maupun mentalnya. Dalam pembangunan dunia, manusia karena aktivitas-aktivitasnya menspesialisasikan dorongan-dorongannya dan memberikan stabilitas pada dirinya sendiri. Karena secara biologis tidak memiliki dunia-manusia, manusia membangun suatu dunia manusia. Manusia menciptakan berbagai jenis alat untuk mengubah lingkungan fisik dan alam dalam kehendaknya. Manusia juga menciptakan bahasa karena melalui bahasa manusia membangun suatu dunia simbol yang meresapi semua aspek kehidupannya. Sama seperti kehidupan materialnya, masyarakat juga sepenuhnya produk manusia. Pemahaman atas masyarakat sebagai suatu produk aktivitas manusia sebagaimana berakar pada eksternalisasi menjadi penting mengingat kenyataan bahwa masyarakat tampak dalam pengertian sehari-hari sebagai sesuatu yang berbeda dari aktivitas manusia. Transformasi produk-produk manusia ke dalam suatu dunia tidak saja berasal dari manusia, tetapi juga kemudian menghadapi manusia sebagai suatu faktisitas di luar dirinya sebagaimana diletakkan dalam konsep objektivasi.

Objektivasi adalah disandangnya produkproduk aktivitas itu (baik fisik maupun mental), suatu realitas yang berhadapan dengan para produsennya semula, dalam bentuk suatu kefaktaan (faktisitas) yang eksternal terhadap dan lain dari produsen itu sendiri. Dunia yang diproduksi oleh manusia kemudian menjadi sesuatu "yang berada di luar sana”. Dunia ini terdiri dari benda-benda, baik materiil maupun nonmaterial yang mampu menentang kehendak produsennya. Sekali sudah tercipta maka dunia ini tidak bisa diabaikan begitu saja. Objektivitas pemaksa dari masyarakat tersebut terlihat jelas dalam prosedur-prosedur kontrol sosial, yaitu prosedur-prosedur yang khusus dimaksudkan untuk memasyarakatkan kembali individuindividu atau kelompok pembangkang. Lembagalembaga politik dan hukum dapat memberi contoh jelas mengenai hal ini. Objektivitas masyarakat mencakup semua unsur pembentuknya. Lembagalembaga, peran-peran, dan identitas-identitas eksis sebagai fenomena-fenomena nyata secara objektif dalam dunia sosial meskipun semua itu tidak lain adalah produk-produk manusia.

$$
\text { Internalisasi adalah peresapan }
$$

kembali realitas tersebut oleh manusia, dan mentransformasikannya sekali lagi dari strukturstruktur dunia objektif ke dalam strukturstruktur kesadaran subjektif. Melalui objektivasi masyarakat menjadi suatu realitas sui generis, unik. Melalui internalisasi, manusia merupakan produk masyarakat. Dari ketiga dialektik inilah kemudian lahir sebuah proses yang disebut sebagai konstruksi sosial yang merupakan hasil ciptaan manusia itu sendiri.

\section{METODE PENELITIAN}

Kajian ini menggunakan pendekatan kualitatif deskriptif untuk menjelaskan visualisasi 
kebencian netizen atas kasus dugaan penistaan agama dalam bentuk meme yang terdapat di media sosial Facebook. Metode yang digunakan dalam kajian ini adalah etnografi virtual. Etnografi virtual adalah metode etnografi yang dilakukan untuk melihat kultur atau fenomena sosial yang terdapat di ruang siber. Sebagaimana dikemukakan Bell (dalam (Nasrullah, 2013), etnografi virtual adalah metode utama dan penting untuk melihat budaya siber yang terdapat di internet. Oleh karenanya, dalam kajian etnografi virtual pola-pola pendekatan penelitian terhadap internet bisa dilakukan tergantung bagaimana individu memandang internet.

Adapun paradigma yang digunakan dalam kajian ini adalah paradigma konstruktivis atau interpretif. Paradigma konstruktivis menyatakan bahwa realitas itu ada dan dalam berbagai bentuk konstruksi mental yang didasarkan pada pengalaman sosial, bersifat lokal dan spesifik, serta tergantung pada pihak yang melakukannya. Karena itu, kebenaran atas realitas sosial bersifat relatif dan tidak bisa digeneralisasikan (Salim, 2006).

\section{HASIL DAN PEMBAHASAN}

Visualisasi kebencian dalam bentuk meme dilakukan kali pertama oleh netizen kepada dua pihak, yakni Basuki Tjahaja Purnama alias Ahok sebagai orang yang disangkakan sebagai penista agama, dan Buni Yani sebagai pihak yang dinilai oleh netizen pendukung Ahok biang keladi kekisruhan. Akan tetapi, dalam perkembangannya baik Ahok maupun Buni Yani sama-sama menjadi objek visualisasi antar-netizen yang kontra maupun pro terhadap Ahok.

Lalu seiring dengan kian meluasnya persoalan tentang kasus dugaan penistaan agama ini, pihak-pihak yang menjadi objek visualisasi netizen dalam bentuk meme pun menjadi bertambah. Tidak hanya berfokus kepada Ahok atau Buni Yani, tetapi juga kelompok yang selama ini aktif menuntut agar
Ahok diproses secara hukum dan kelompok yang membela Ahok. Melalui meme yang diproduksi dan direproduksinya netizen membuat berbagai penggambaran terhadap dua kelompok tersebut.

Selain itu, pribadi atau individu yang terkait dengan persoalan dugaan penistaan agama ini juga tidak terlepas dari objek visualisasi netizen. Antara lain adalah Ketua Umum Front Pembela Islam (FPI) Habib Rizieq, Ketua Umum Partai Demokrasi Perjuangan Indonesia (PDIP) Megawati Soekarno, Kapolri Jenderal Polisi Tito Karnavian, dan Presiden Joko Widodo. Berdasarkan penelusuran terhadap berbagai akun pribadi dan akun grup, berikut ini sejumlah meme yang diproduksi dan direproduksi oleh netizen tentang parapihak sebagaimana telah dikemukakan di atas.

\section{Visualisasi tentang Buni Yani}

Sebagai pihak yang mengedit dan mengupload video Ahok di media sosial, Buni Yani tidak lepas objek visualisasi dalam bentuk meme oleh para netizen. Meski jumlahnya tidak sebanyak Ahok, meme yang diproduksi dan direproduksi netizen tentang Buni Yani juga mengekspresikan bentuk kebencian di satu sisi, karena dinilai sebagai biang kerok terjadinya kekisruhan. Di sisi lain netizen juga mengekspresikan bentuk pembelaan karena di-edit ataupun tidak video tersebut oleh Buni Yani, secara faktual Ahok tetap melakukan penistaan agama.

Gambar 1A dan 1B adalah dua contoh meme yang menunjukkan kebencian netizen terhadap Buni Yani. Pada Gambar 1A, netizen menyebut tindakan Buni Yani yang mengedit dan mengunggah video Ahok sebagai tindakan idiot. Tepat di bawah foto Buni Yani tertulis kalimat: Karena ulahnya yang idiot akibatnya terjadi demo besar yang menimbulkan kerugian masyarakat tak terhitung jumlahnya. Sementara itu, visualisasi meme pada Gambar 1B jauh lebih sarkastik menampilkan 
foto kerbau dengan Buni Yani. Di atas foto tertulis kalimat: Buni Yani: Adanya kata 'pakai' atau tidak ada tidak penting. Lalu di bawah foto tertulis: Buni Yani dilamar (pakai/kata pakai diberi tanda $\mathrm{X)}$ Kebo, serta tambahan sejumlah emoticon di bawahnya. Gambar 1B ini seolah ingin menjelaskan bahwa kata pakai adalah persoalan substantif yang jika dihilangkan akan mengubah makna.

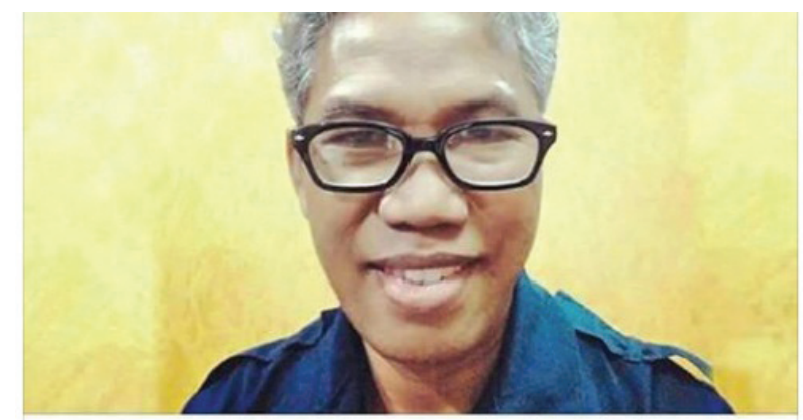

Buni Yani: Saya Menghilangkan Satu Kata Bukan Mengakui Kesalahan! eskaha.com

KARENA ULAHNYA YANG IDIOT
AKIBATNYA TERJADI DEMO
BESAR YANG MENIMBULKAN
KERUGIAN MASARAKAT YANG
TAK TERHITUNG JUMLAHNYA

Gambar 1A

Buni Yani:

adanya kata 'pakai' atau tidak ada, tidak penting

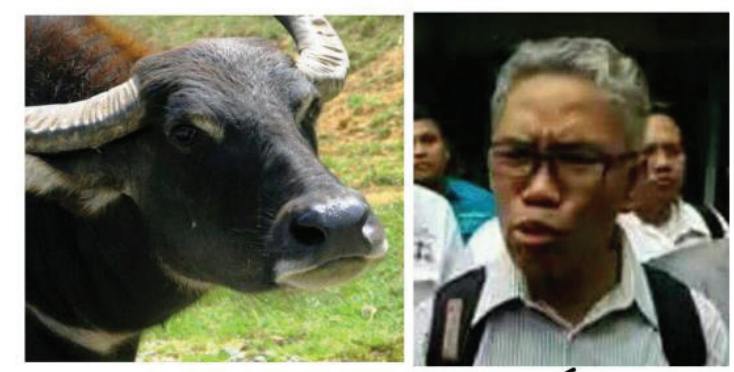

Buni Yani Dilamar (PA) KAI) Kebo

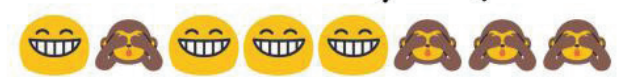

Gambar 1B

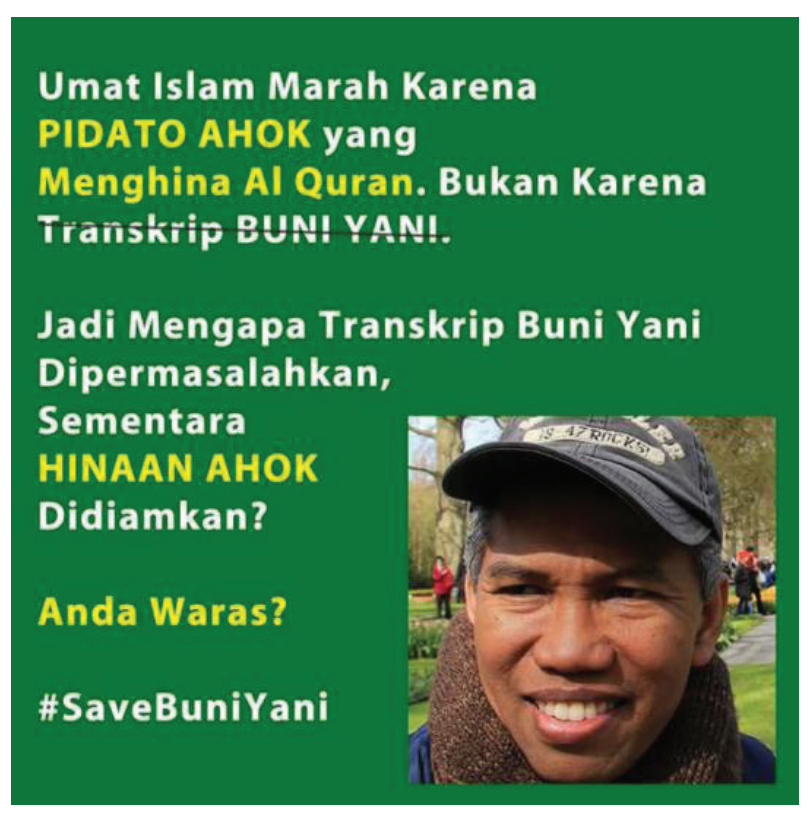

Gambar 2A

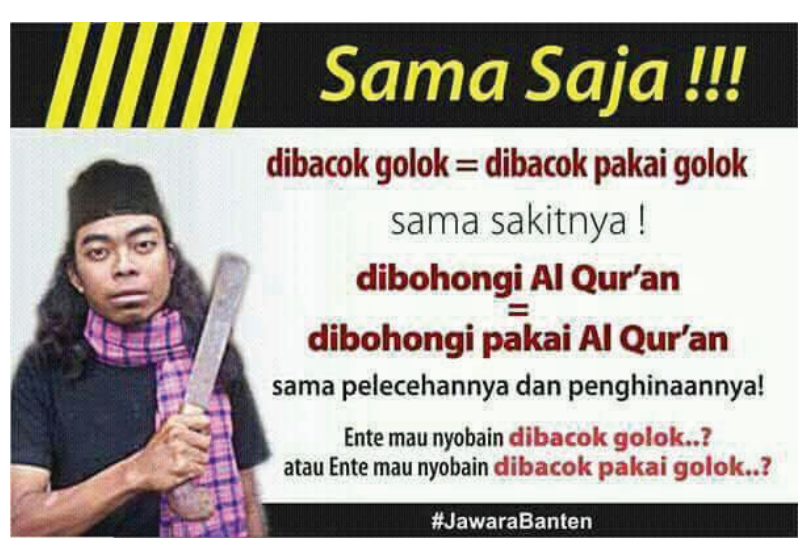

Gambar 2B

Adapun Gambar 2A dan 2B adalah dua contoh meme tentang pembelaan terhadap Buni Yani. Meme pada Gambar2A hanya bersifat normatif berupa foto Buni Yani dengan kalimat: Umat Islam Marah karena PIDATO AHOK yang menghina Al Quran. Bukan karena Transkip Buni Yani. Jadi Mengapa Transkip Buni Yani Dipermasalahkan, Sementara HINAAN AHOK Didiamkan? Anda Waras? \#SaveBuniYani. Meme pada Gambar 2B lebih menyoal pada substansi kata pakai. Meme bergambar pria berpeci dengan rambut gondrong dan tangan kanannya memegang sebilah golok itu menyatakan bahwa dibacok golok = dibacok pakai golok sama sakitnya! Dibohongin Al Qur'an = 
dibohongin pakai Al Quran sama pelecehannya dan penghinaannya! Kalimat lainnya adalah: Ente mau nyobain dibacok golok...? atau Ente mau nyobain dibacok pakai golok...? dengan tagar di bawahnya \#JawaraBanten.

\section{Visualisasi tentang Ahok}

Secara garis besar visualisasi netizen terhadap Ahok melalui meme mengekspresikan kepada dua hal. Pertama, ekspresi kebencian karena menilai Ahok sebagai penista agama. Kedua, ekspresi pembelaan terhadap Ahok yang dinilai tidak memiliki maksud menistakan agama tertentu dalam dialognya dengan masyarakat di Kepulauan Seribu. Dibandingkan dengan meme Buni Yani, meme yang diproduksi dan direproduksi netizen tentang Ahok lebih banyak jumlahnya, berisi berbagai sindiran kebencian ataupun kebencian, di antaranya sebagaimana pada Gambar 3A, 3B, dan 4A, 4B.

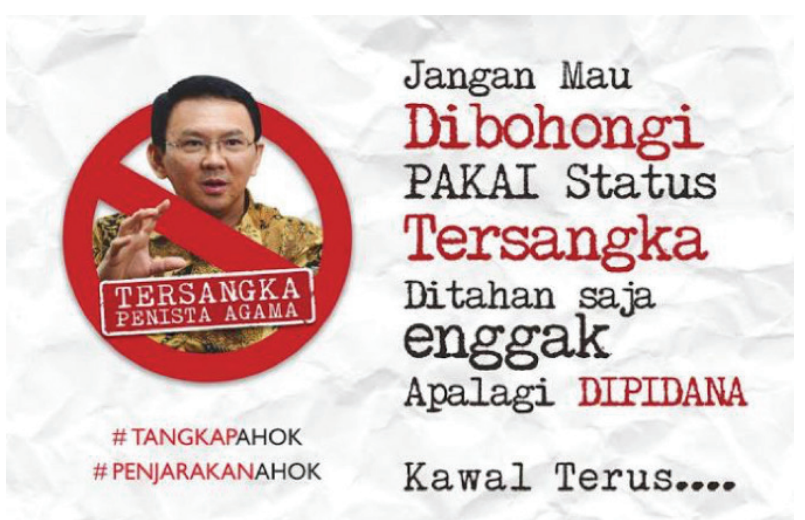

Gambar 3A

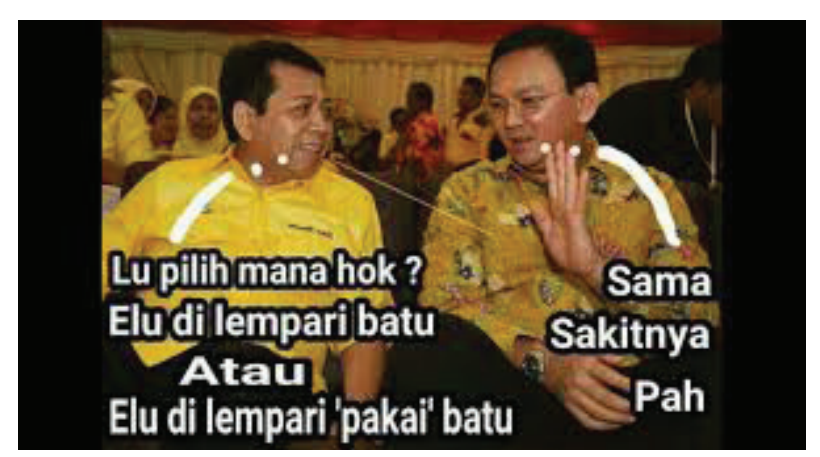

Gambar 3B
Meme pada Gambar 3A berisi gambar Ahok dengan tulisan Tersangka Penista Agama dan di sampingnya terdapat kalimat: Jangan Mau Dibohongin PAKAI Status Tersangka Ditahan Saja enggak Apalagi DIPIDANA dengan tagar di bawahnya \#TANGKAP AHOK, seolah mempertanyakan sekaligus meragukan keseriusan aparat penegak hukum dalam menyelesaikan kasus tersebut. Meme pada Gambar 3B berupa foto pertemuan antara Ketua Umum Partai Golkar Setya Novanto dan Ahok dalam sebuah acara yang diimbuhi kalimat percakapan imajiner antara keduanya. Dalam percakapan imajiner itu Novanto bertanya: Lu pilih mana hok? Elu dilempari batu atau elu dilempari 'pakai' batu, yang dijawab oleh Ahok: Sama Sakitnya Pah. Meskipun dibuat simpel dan sederhana, meme tersebut cukup karikatif sekaligus menohok.

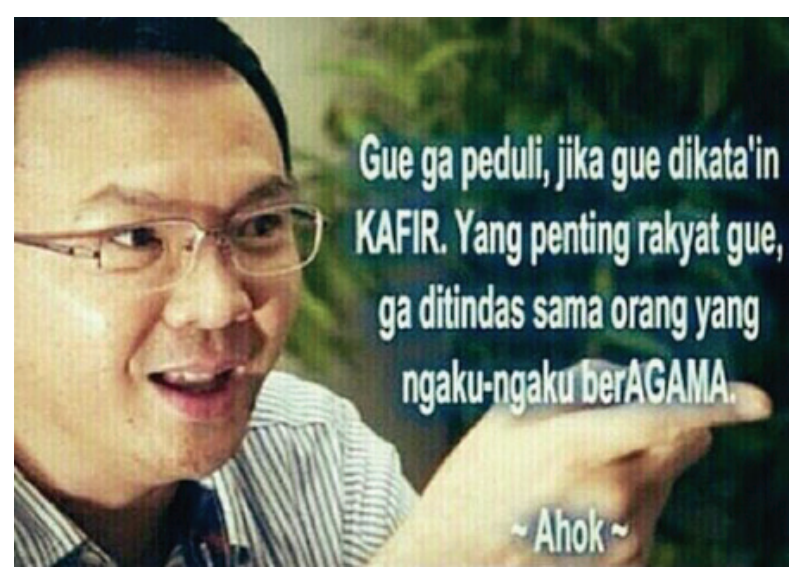

Gambar 4A

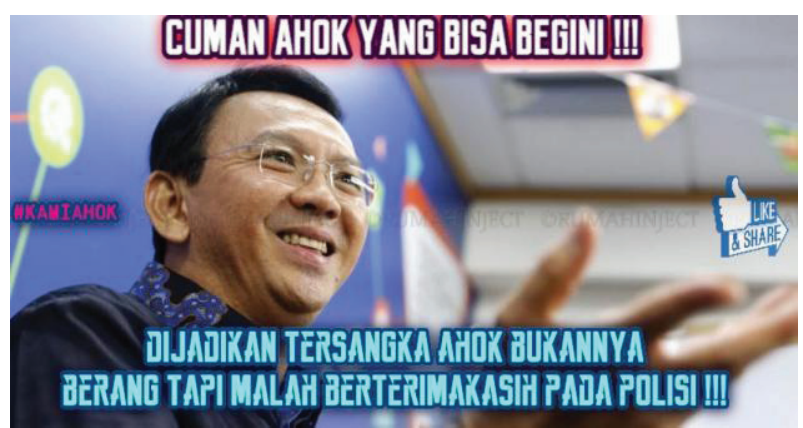

Gambar 4B 
Berikutnya adalah meme pada Gambar 4A dan 4B. Dua meme tersebut berisi pembelaan sekaligus memvisualisasikan kebanggaan netizen terhadapnya. Meme pada Gambar 4A berisi foto Ahok dengan mimik muka santai seolah berkata: Gue ga peduli, jika gue dikata'in KAFIR. Yang penting rakyat gue, ga ditindas sama orang yang ngakungaku berAGAMA. Gambar 4B memvisuliasikan tentang sikap gentleman Ahok yang meskipun dijadikan tersangka ia tidak marah, tetapi justru berterima kasih kepada polisi. Dalam visualisasi itu ditampilkan foto Ahok yang tersenyum dengan kalimat: CUMAN AHOK YANG BISA BEGINI!!! DIJADIKAN TERSANGKA AHOK BUKANNYA BERANG TAPI MALAH BERTERIMAKASIH PADA POLISI!!!!

Visualisasi terhadap Kelompok Pro Ahok dan Kelompok Kontra Ahok

Seperti halnya meme tentang Ahok, netizen juga banyak memproduksi meme kebencian dan pembelaan terhadap kelompok yang pro terhadap Ahok ataupun kepada kelompok yang kontra Ahok. Dalam visualisasinya mereka menampilkan gambar dan kalimat yang beragam sebagai gambaran dari sikap mereka terhadap kedua kelompok baik yang pro terhadap ataupun yang kontra terhadap Ahok. Berikut beberapa contohnya.

\section{a. Visualisasi Netizen Pro Ahok terhadap Kelompok Kontra Ahok}

Dari begitu banyak meme yang menyerang kelompok kontra Ahok, ada beberapa di antaranya yang memanfaatkan ketokohan pihak tertentu untuk digunakan sebagai bentuk pembelaan terhadap Ahok. Gambar 5A, netizen memanfaatkan ketokohan Buya Syafii Maarif yang dalam berbagai kesempatan justru mengkritik sikap orang-orang yang kontra terhadap Ahok. Dalam meme tersebut foto Buya Syafii yang beberapa pernyataannya direpresentasikan sebagai bentuk pembelaan terhadap Ahok disandingkan dengan foto Ketua FPI Habib Rizieq yang dikenal aktif menyerang Ahok, sedangkan di atasnya terdapat kalimat: $S K A K$ MATT UNTUK FPI DAN ANTI AHOK...!!! BUYA SYAFII MAARIF: AHOK TIDAK MENGENAL ALQURAN, AHOK HANYA KRITIK ORANG YANG GUNAKAN SURAT AL MAIDAH AYAT 51.

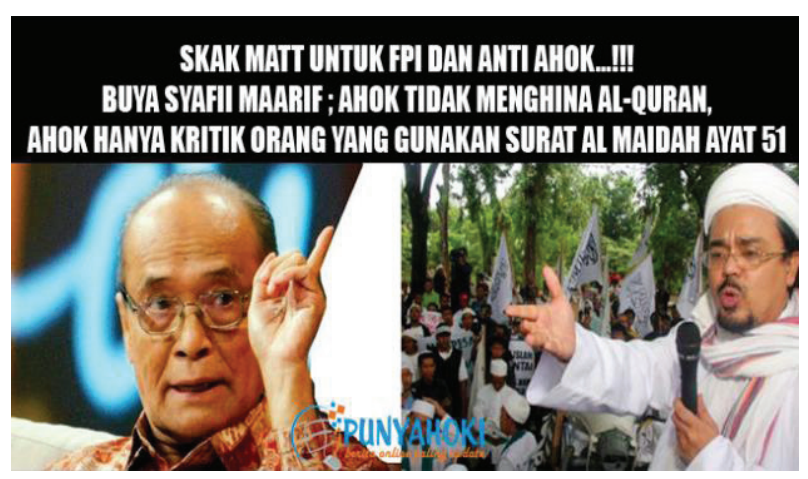

Gambar 5A

\section{Tahukah kalian? ulama-ulama ini dihina, \& dicaci oleh mereka yang ngaku Muslim, karena ulama-ulama ini tidak mendukung aksi politik berkedok bela agama mereka.}

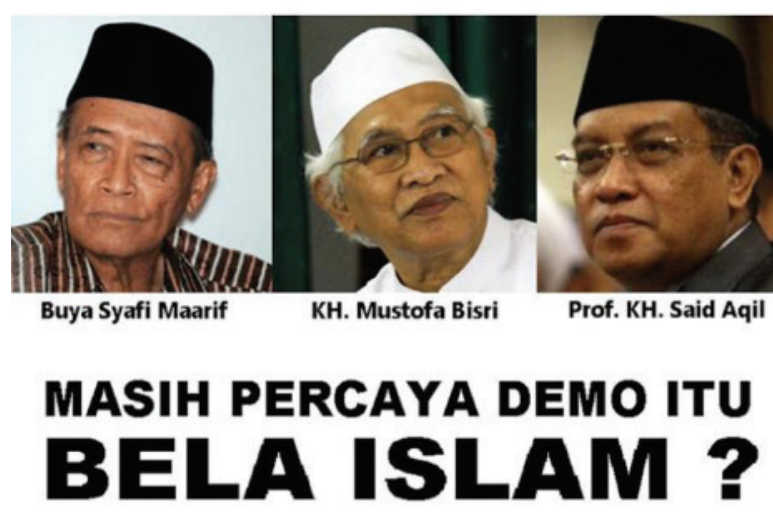

Gambar 5B 


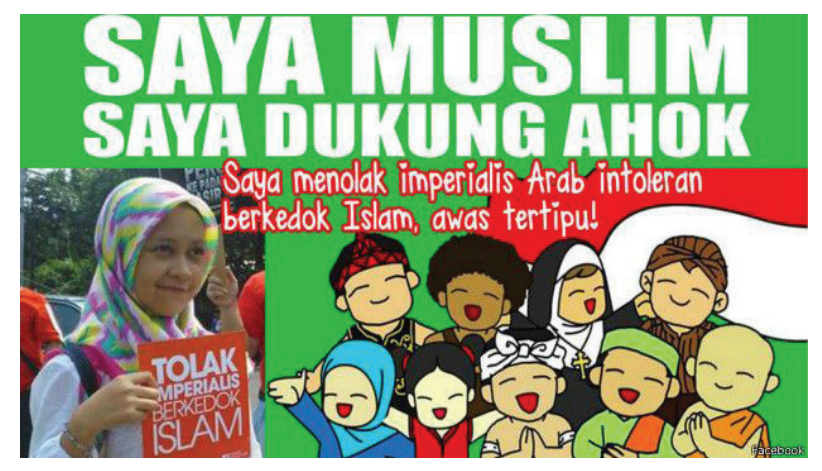

Gambar 6A

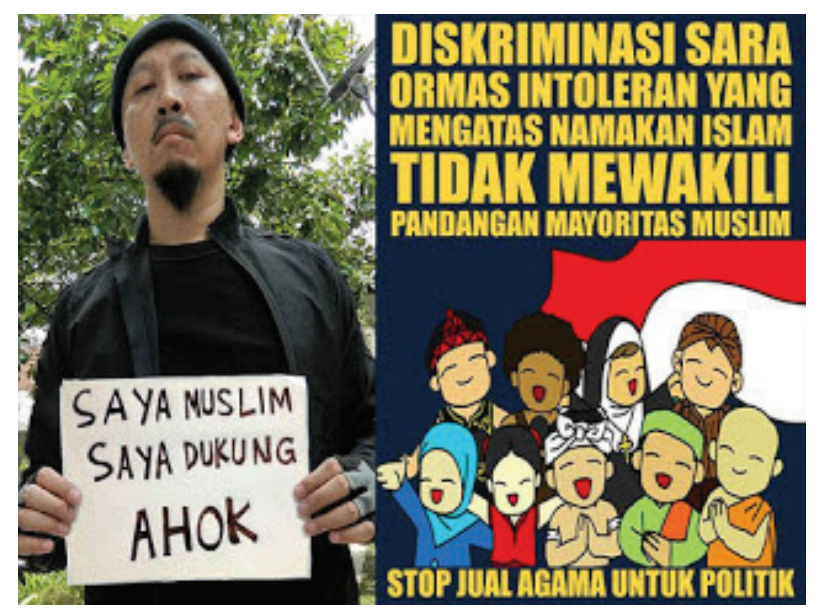

Gambar 6B

Pada meme yang lain seperti Gambar 5B, netizen menampilkan foto tiga ulama yang memiliki sikap dan pandangan berbeda terhadap persoalan penistaan agama ini, yaitu Buya Syafii Maarif, K.H. Mustofa Bisri, dan K.H. Said Aqil. Sikap dan pandangan yang berbeda dari mereka itulah yang dijadikan objek untuk menyerang balik kelompok yang selama ini kontra terhadap Ahok melalui meme-nya. Di atas foto ketiganya ditulis kalimat: Tahukah kalian? Ulama-ulama ini dihina \& dicaci oleh mereka yang ngaku Muslim, karena ulamaulama ini tidak mendukung aksi politik berkedok bela agama mereka.

Selain menampilkan para tokoh Islam yang berseberangan, netizen pro Ahok juga memproduksi dan mereproduksi meme lain, seperti pada Gambar 6A dengan pernyataan bahwa meskipun muslim, mereka tetap mendukung Ahok melalui visualisasi perempuan berjilbab membawa tulisan: TOLAK IMPERIALIS BERKEDOK ISLAM dan gambar kartun yang merepresentasikan kebhinekaan. Di dalam meme tersebut juga ditulis kalimat: SAYA MUSLIM SAYA DUKUNG AHOK. Saya menolak imperialis Arab intoleran berkedok Islam, awas tertipu!

Senada dengan Gambar 6A, meme pada Gambar 6B juga memvisuliasikan kebencian melalui foto seorang berjanggut dengan tulisan SAYA MUSLIM SAYA DUKUNG AHOK dan gambar kartun yang juga merepresentasikan kebhinekaan, serta tulisan dengan kalimat: DISKRIMINASI SARA ORMAS INTOLERAN YANG MENGATASNAMAKAN ISLAM TIDAK MENCERMINKAN PANDANGAN MAYORITAS MUSLIM. STOP JUAL AGAMA UNTUK POLITIK.

\section{b. Visualisasi Netizen Kontra Ahok terhadap Kelompok Pro Ahok}

Aksi turun ke jalan baik yang dilakukan baik kelompok kontra Ahok maupun kelompok pendukung Ahok tidak luput dari objek visualisasi netizen untuk menggambarkan sikap kebencian dan pembelaannya dalam wujud meme. Banyak netizen yang kontra terhadap kelompok pro Ahok memproduksi dan mereproduksi meme dengan menampilkan foto tentang perbedaan aksi turun ke jalan yang dilakukan kedua kelompok tersebut. Meme dalam Gambar 7A menampilkan perbedaan aksi turun ke jalan kelompok muslim pada 4 November 2016 atau biasa dikenal dengan istilah Aksi 411 dengan aksi Parade Bhinneka Tunggal Ika. Meme ini menyindir Aksi Parade Bhinneka Tunggal Ika yang jumlah massanya tidak sebanyak Aksi 411, dengan diberi emoticon besar bertanda sedih.

Meme pada Gambar 7B, dengan ilustrasi foto peristiwa aksi turun ke jalan netizen menggambarkan siapa sesungguhnya Penjaga Bhinneka Tunggal Ika Itu. Aksi 411 yang meskipun diikuti begitu banyak massa tetapi berlangsung 
tertib, bahkan rumput pun terhindar dari kerusakan, atau aksi Parade Bela Ahok yang hanya diikuti sedikit orang tetapi taman kota menjadi rusak dan kotor akibat ulah mereka menduduki rumput dan membuang sampah sembarangan, dengan tulisan di bawahnya: Jaga Rumput Aja Gak Bisa.

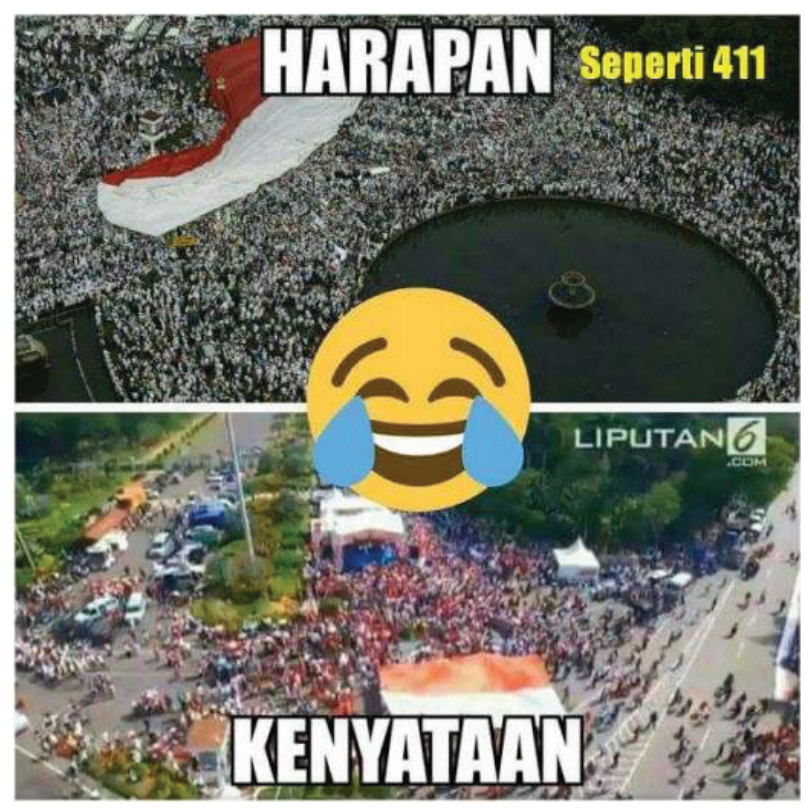

Gambar 7A

\section{Penjaga Bhinneka Tunggal Ika}
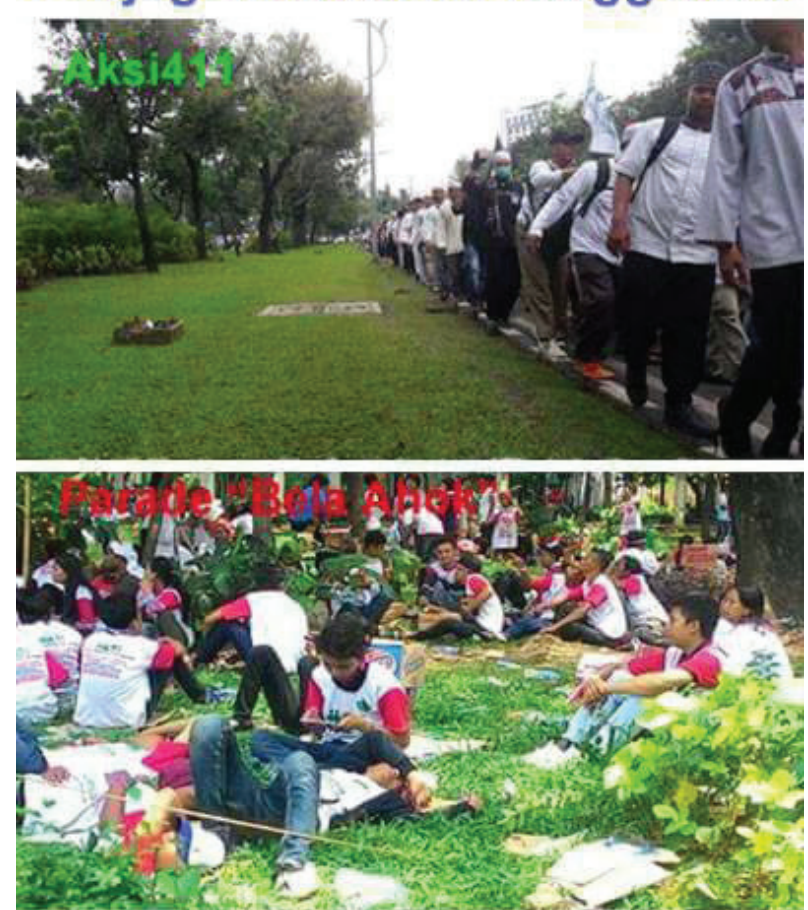

Jaga Rumput aja Gak Bisa

Gambar 7B
Demikian pula dengan meme pada Gambar 8A. Foto peserta Parade Bhinneka Tunggal Ika yang tengah beristirahat sambil menduduki dan meniduri rumput di taman kota plus sampah berserakan, menjadi objek untuk memvisualisasikan ejekan netizen terhadap kelompok pro Ahok. Di dalam foto itu terdapat seorang yang tengah tiduran kemudian dituliskan kalimat kutipan seolah ungkapannya. Kutipan itu berisi: ENAKAN TIDURAN WOY YG PENTING SUDAH DAPAT NGANUNYA.... Tidak cukup di situ, foto tersebut juga diimbuhi kalimat: Metro Tivu mana sih Kok nggak mau ngeliput kita yang lagi ngrusak taman....

Selain meme dengan visualisasi tentang aksi kelompok pro Ahok, ada juga meme dengan tokoh tertentu yang dijadikan sebagai patron untuk membangun kebencian terhadap kelompok tersebut sebagaimana pada Gambar 8B. Meme tersebut menampilkan sosok Ketua FPI Habib Rizieq yang tengah memegang mikrofon, sambil tangannya yang satu lagi memegangi jidat seolah menyatakan tidak habis pikir terhadap aksi yang dilakukan oleh kelompok pendukung Ahok. Di samping foto tersebut tertulis kalimat besar: Aneka Peristiwa Aksi 412 yang diikuti anak kalimat berikut ini: Panitia Berantem, Peserta Dibayar, Berebut Makanan, Sampah Berserakan, Disapu Puting Beliung, Bendera HMI Dicatut. Di bawahnya ditulis Catatan: Harry Clinton pernah usulkan agar tanggal 4 November jadi HARI HEWAN LIAR. 


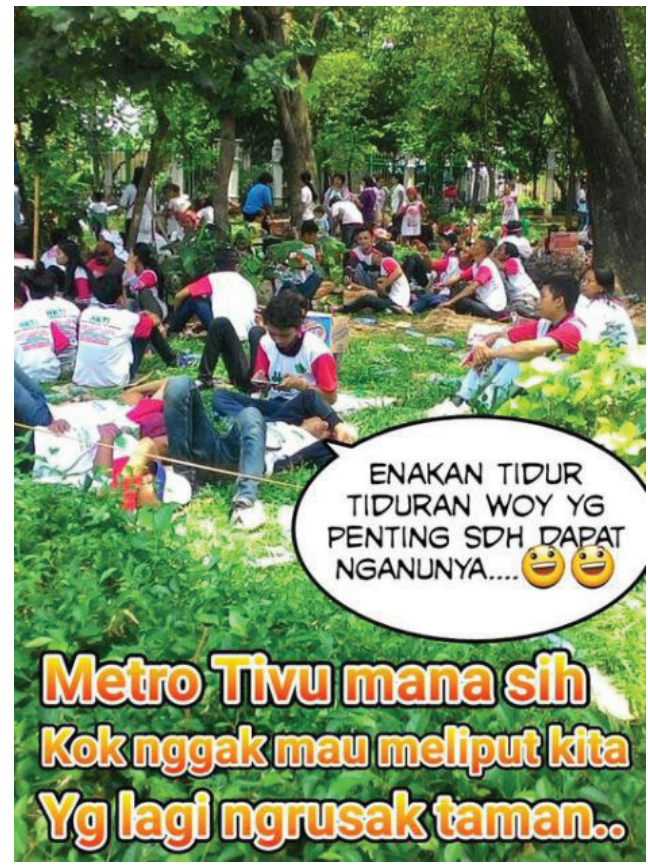

Gambar 8A

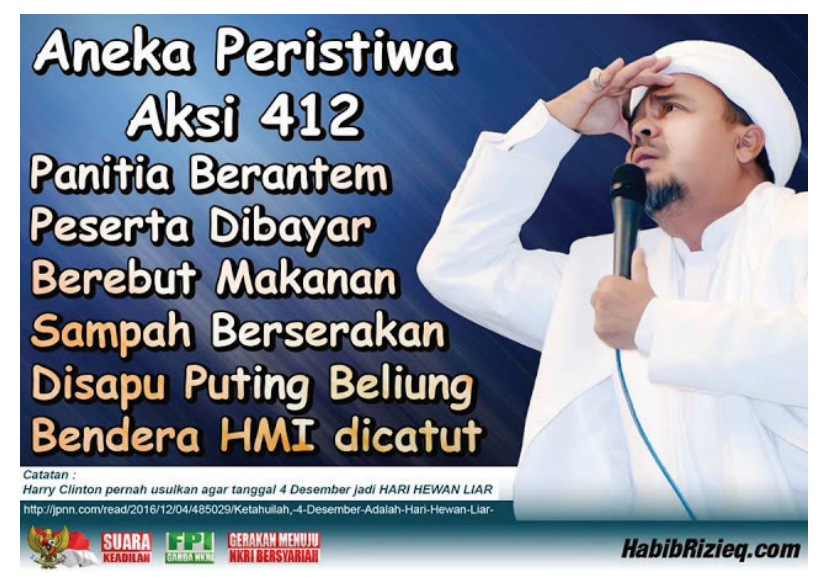

Gambar 8B

\section{Visualisasi tentang Habib Rizieq}

Di antara tokoh atau sosok yang banyak dijadikan meme oleh netizen dalam kasus dugaan penistaan agama adalah Ketua Front Pembela Islam (FPI) Habib Rizieq. Sosok ini dikenal sebagai orang yang paling getol mendesak agar pemerintah dan aparat penegak hukum mengusut kasus penodaan tersebut. Tidak hanya itu, ia juga aktif memimpin berbagi aksi turun ke jalan bersama sejumlah ulama lain. Karena itu, sosok Habib Rizieq mendapat perhatian begitu rupa dari netizen, baik yang pro maupun kontra terhadap dirinya. Bagi netizen yang pro, meme yang diproduksi dan direproduksinya memvisualisasikan dirinya sebagai tokoh dan aktor panutan. Ia dibela begitu rupa.

Penggambaran Habib Rizieq sebagai pembela umat Islam oleh netizen yang pro terhadap dirinya, berbanding terbalik dengan penggambaran melalui meme oleh netizen yang kontra. Mereka memproduksi dan mereproduksi meme dengan menampilkan visualisasi kebencian begitu rupa. Untuk lebih jelasnya bagaimana netizen yang pro dan kontra melakukan visualisasi terhadap sosok yang satu ini dapat dilihat pada meme-meme berikut ini.

\section{a. Visualisasi Pembelaan}

Meme pada Gambar 9A adalah meme pembelaan netizen terhadap Buni Yani dengan menampilkan sosok Habib Rizieq berpose sedang berceramah. Di sampingnya dituliskan kalimat berikut ini: "Oooiii....Polri Bukan Buni Yani yang salah TAPI AHOK YANG SALAH" JANGAN ALIHKAN ISSUE....!!! Pada bagian lain dalam meme itu juga ditulis kalimat: "Buni Yani hanya mengunggah sebuah video di Facebook yang berisi pidato PEJABAT publik yang dilontarkan di depan PUBLIK, bukan dalam rapat tertutup pejabat. Itu pun bersumber dari rekaman RESMI video Pemprov DKI Jakarta yang singgah pertama kali dalam akun Youtube resmi Pemprov DKI".

Meme pada Gambar 9B menampilkan sosok Habib Rizieq yang sedang berpidato dengan tangan kiri memegang mikrofon dan tangan kanan mengarahkan telunjuknya ke arah jidat. Pose ini kemudian ditimpali dengan kalimat: Jadi, rangkaiannya sangat bahwa umat Islam WAJIB menerapkan HUKUM ALLAH SWT, dan tidak boleh menjadikan NON MUSLIM (Yahudi \& Nashrani) sebagai PEMIMPIN sebab mereka tidak akan menerapkan HUKUM ALLAH, yang dilanjutkan dengan kalimat berikutnya: MIKIR DONG MIKIIIR...!!! 


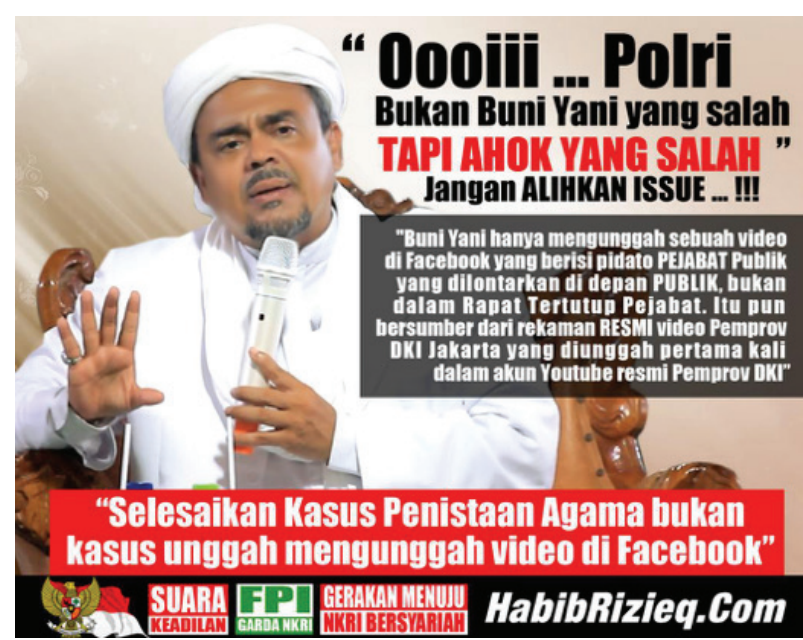

Gambar 9A

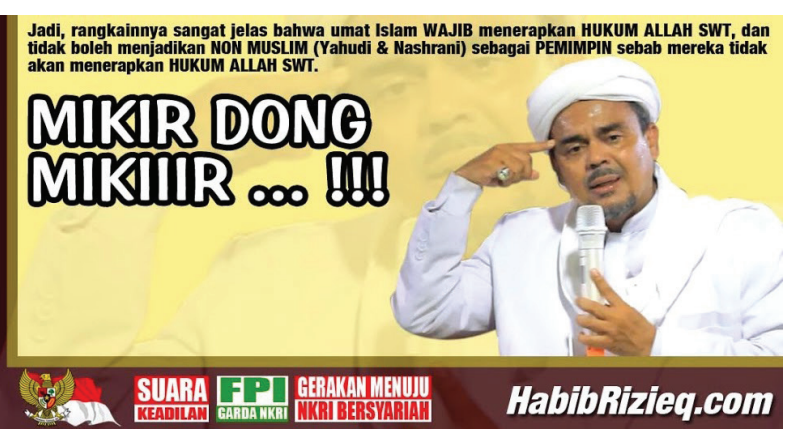

Gambar 9B

\section{b. Visualisasi Kebencian}

Salah satu meme yang mengekspresikan kebencian begitu rupa terhadap Habib Rizieq adalah sebagaimana dalam Gambar 10A. Melalui memenya netizen menuliskan kalimat kebenciannya dengan kata-kata: PIMPINAN FRONT PEMBELA

\section{ISLAM plesetin Pancasila jadi PancaGila}

PantatCina dengan foto Habib Rizieq bertuliskan; bangcaaatttt... Di bawahnya tertulis ungkapan: menghina Pancasila adalah karangan Soekarno, ketuhanannya ada di PANTAT, tapi... nggak ada yang berani MELAPORKAN KE POLISI nggak ada yang berani bilang mulutnya kotor...

Adapun meme sebagaimana Gambar 10B berisi ejekan netizen pro Ahok terhadap Habib Rizieq seolah hendak mengatakan bahwa ia tidak mungkin menang melawan Ahok. Ejekan itu divisualisasikan dengan adegan pertarungan tinju antara Habib Rizieq melawan Ahok. Habib Rizieq yang terkena pukulan hook kanan Ahok hingga

\section{PIMPINAN FRONT PEMBELA ISLAM plesetin Pancasila jadi PancaGila PantatCina}

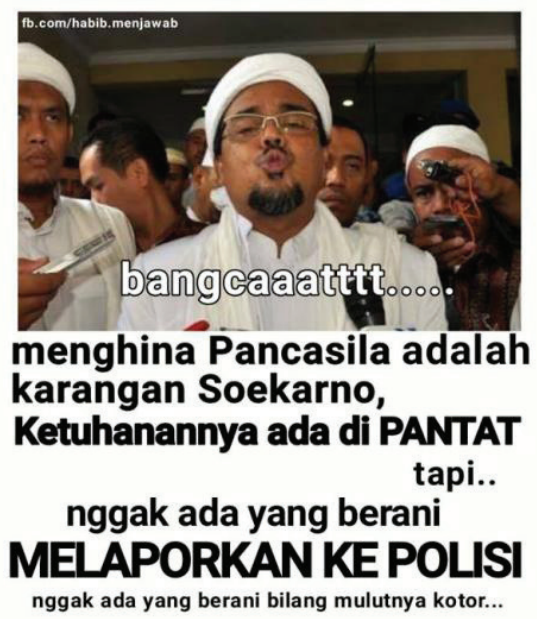

Gambar 10B

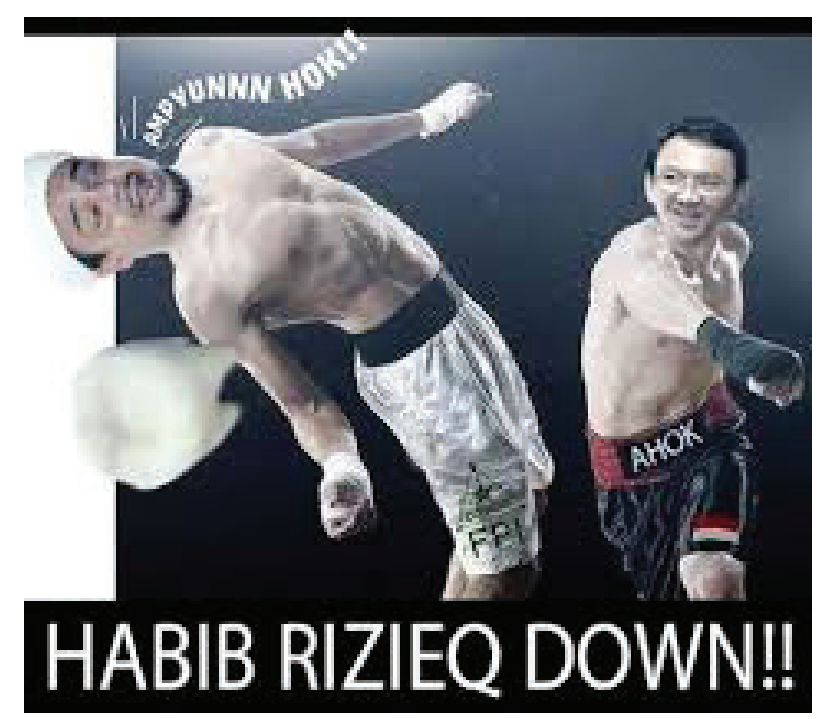

Gambar 10A

membuatnya terbang melayang sambil mulutnya mengeluarkan ucapan: AMPYUNNN HOK!! Tepat di bawah foto keduanya tertulis kalimat: $H A B I B$ RIZIEQ DOWN!!

Visualisasi tentang Megawati Soekarnoputri

Berdasarkan penelusuran terhadap berbagai akun baik pribadi maupun akun grup, meme netizen tentang sosok Megawati lebih dominan memvisualisasikan kebencian. Meme-meme tersebut diproduksi dan direproduksi khususnya oleh netizen yang kontra terhadap Ahok. Mereka menganggap, 


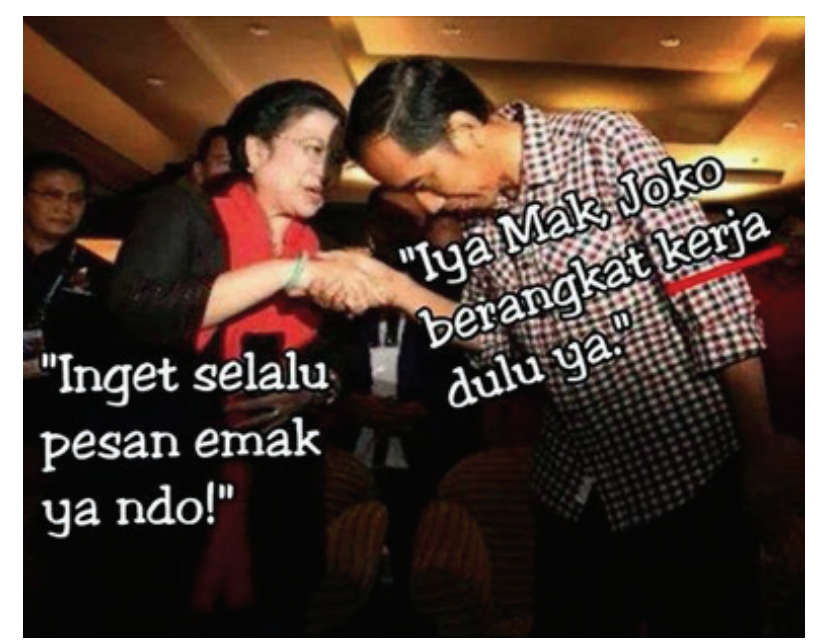

Gambar 11A

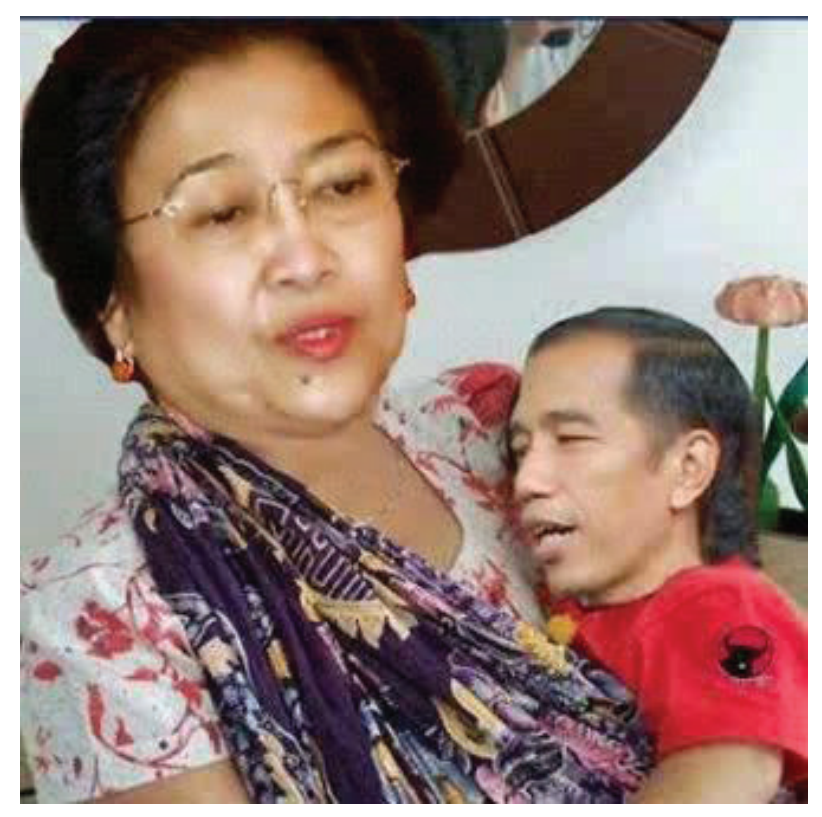

Gambar 11B

sebagai Ketua Umum PDIP, Megawati adalah sosok di balik pencalonan Ahok sebagai Gubernur DKI dan memiliki pengaruh luar biasa di pemerintahan. Ia juga dinilai sosok yang tidak pro terhadap kepentingan umat Islam. Bahkan Presiden Jokowi pun berada di bawah pengaruhnya sehingga dalam menyikapi kasus dugaan penistaan agama ini ia terkesan berpihak terhadap Ahok.

Meme pada Gambar 11A menampilkan foto dengan pose Jokowi mencium tangan Megawati Soekarnoputri. Penggambaran bahwa Jokowi berada di bawah pengaruh Mega dikesankan dalam kalimat ungkapan Megawati yang dibuat netizen melalui kata-kata: "Ingat selalu pesan emak ya
Indo!” yang dijawab oleh Jokowi: "Iya Mak, Joko berangkat kerja dulu ya."

Meme pada Gambar 11B berisi croping-an Megawati yang tengah menimang Jokowi berkaus merah dengan lambang PDIP. Meskipun tidak menampilkan kalimat ungkapan atau penjelas lainnya, meme yang sangat sarkastis itu cukup memberikan penggambaran bahwa Mega sebagai seorang ibu melakukan penguasaan begitu rupa terhadap Jokowi yang divisualisasikan sebagai bayi atau anaknya.

\section{Visualisasi tentang Tito Karnavian}

Sama halnya dengan Megawati, visualisasi netizen terhadap Kapolri Jenderal Polisi Tito Karnavian lebih banyak menggambarkan ekspresi kebencian. Melalui berbagai meme-nya netizen melakukan penggambaran Kapolri sebagai pihak yang melakukan keberpihakan terhadap Ahok, sebagaimana tergambarkan begitu jelas pada dua meme berikut ini.

Meme pada Gambar 12Amemvisualisasikan ketidakadilan Kapolri dalam menangani kasus dugaan penistaan agama. Melalui visualisasinya netizen memberikan penggambaran bahwa Kapolri bersikap tebang pilih. Ia dinilai begitu reaktif terhadap pihak-pihak yang anti Ahok dengan menetapkan status mereka sebagai tersangka, sedangkan terhadap orang-orang yang pro terhadap Ahok, tidak ada sikap hukum apa pun darinya. Dalam meme tersebut netizen mempertanyakan sikapnya itu dengan kata-kata tepat berdampingan dengan foto Kapolri: SUDAH LAKUKAN KERJA TERBAIK? yang (seolah) dijawab, Kapolri: Kami sudah melakukan kerja terbaik tapi mengapa publik masih belum percaya kepada Polri. Tidak cukup di situ, netizen melalui meme-nya itu menambahkan kata-kata di bawahnya: Tersangka kan Ahok, Megawati, Ade Armando dll LAMBAT BANGET Tapi tersangka-kan Anti Ahok CEPET BANGET GIMANA RAKYAT MAU PERCAYA diimbuhi kata 
HA..HA..HA.. tepat di bawah foto seorang pria yang sedang tertawa.

Meme pada Gambar 12B netizen memvisualisasikan Kapolri sebagai pembohong terkait saksi ahli dari Mesir dalam kasus Ahok. Visualisasi dilakukan melalui kata-kata: SAKSI AHLI DARI MESIR SIAPA YANG BERDUSTA KAPOLRI ATAU AHOK? Dengan tautan di bawahnya berupa tiga potong berita online seputar pemanggilan saksi ahli dari Mesir untuk kepentingan pemeriksaan terhadap Ahok dalam kasus dugaan penistaan agama, seolah hendak memberikan bukti bahwa Kapolri-lah yang berdusta dalam persoalan tersebut.

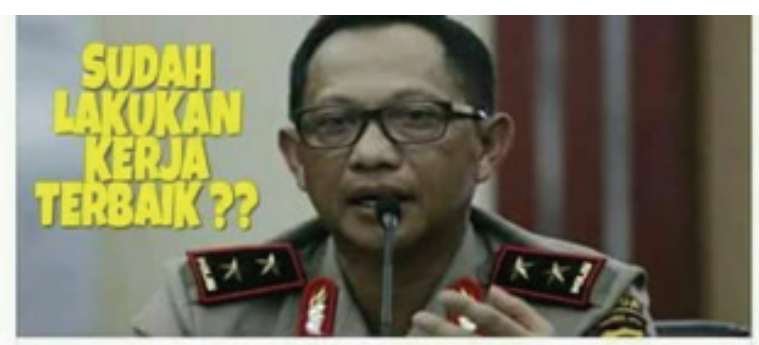

Kapolri : Kami Sudah Melakukan yang Terbaik, Tapi Mengapa Publik Masih Kurang Percaya Kepada Polri
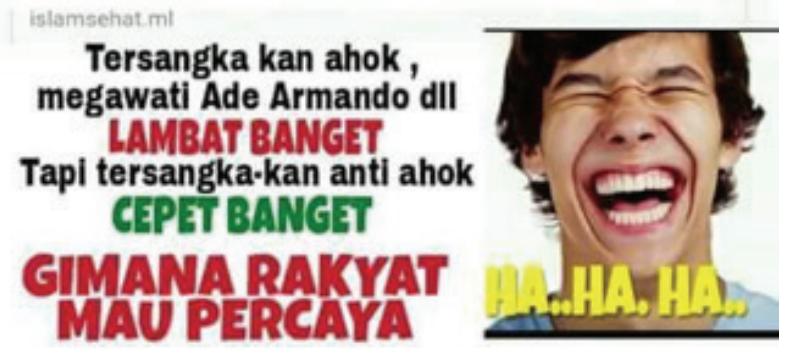

Gambar 12A
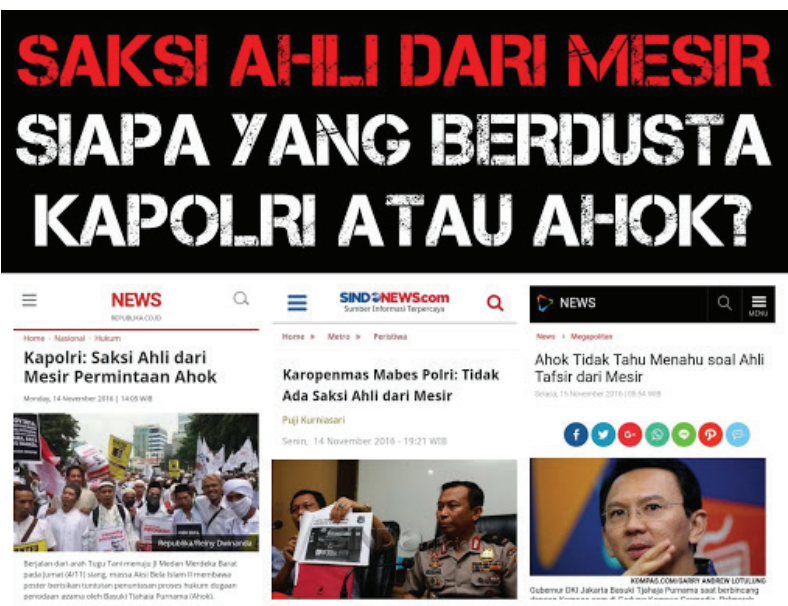

Gambar 12B

\section{Visualisasi tentang Joko Widodo}

Bukan hanya Megawati dan Kapolri, Presiden Joko Widodo juga menjadi objek visualisasi begitu rupa oleh netizen. Namun, meme tentang Jokowi lebih banyak berisi ekspresi kebencian daripada ekspresi pembelaan atau dukungan. Di antaranya sebagaimana pada Gambar 14A. Ekspresi kebencian pada gambar tersebut divisualisasikan melalui foto Habib Rizieq dengan kalimat seperti puisi berisi cemooh dan sindiran berikut ini.

Sejak kau pimpin negara

Muncul banyak perkara

PKI makin meraja-lela

Liberal makin angkat dada

Non Muslim Pimpin Jakarta

Di Sumber Waras, dia dijaga

Di Reklamasi, dia juga dibela

Hingga berani nista agama

4 November 2016 siang

Habib \& Ulama datang

Menunggumu hingga petang

Engkau menghilang

Kini, saat umat marah

Kau mulai beramah tambah

Datang sini datang sana

Undang sini undang sana

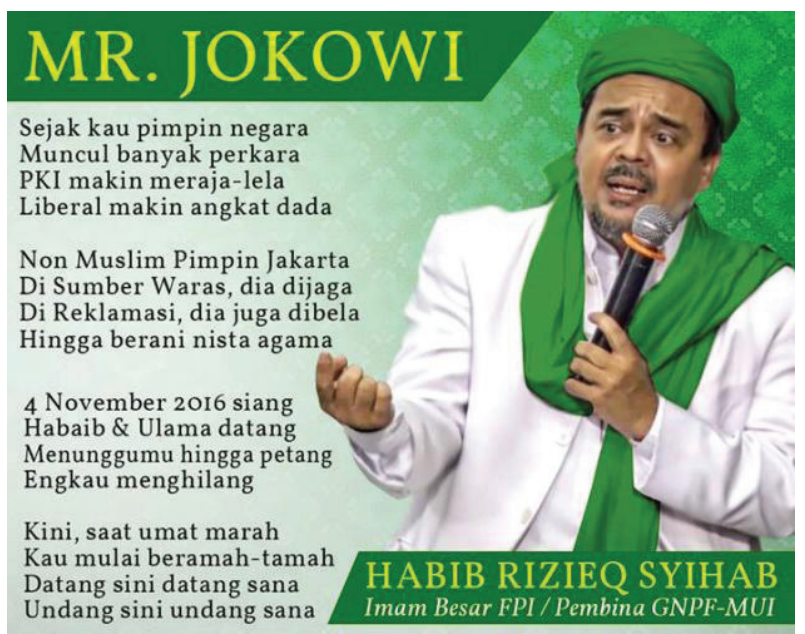

Gambar 13A 


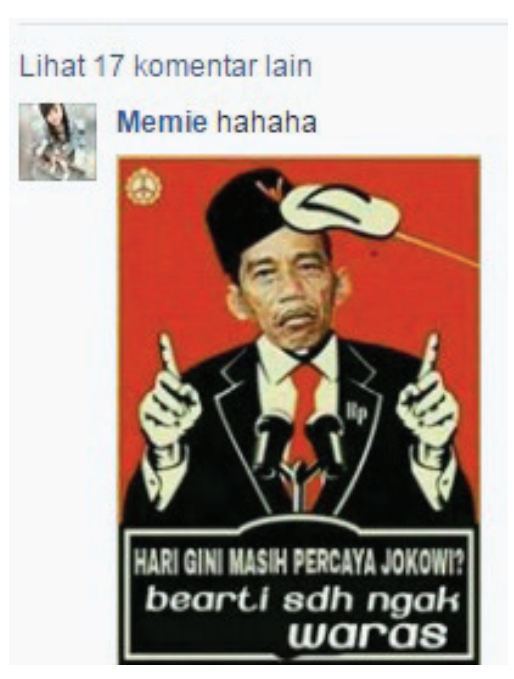

Gambar 13B

Meme berikutnya seperti pada Gambar 13B, ekspresi kebencian divisualisasikan begitu vulgar melalui croping foto Jokowi yang seolah sedang berpidato. Pecinya nyaris terlepas karena terkena lemparan sandal. Tepat di bawah foto tertulis kalimat: HARI GINI MASIH PERCAYA JOKOWI? bearti sdh ngak waras. Pada meme sebagaimana Gambar 13C Jokowi dengan foto sikap sempurna sambil melakukan hormat diasosiasikan sebagai orang yang harus diwaspadai melalui ungkapan kata-kata: Waspadalah! Antek Asing Wajah Pribumi.

Pada meme lainnya sebagaimana Gambar 13D Jokowi digambarkan sebagai orangnya Megawati melalui visualisasi foto Megawati berkedok Jokowi. Di dalam meme tersebut tertulis: Jokowi bukan KITA, JOKOWI ADALAH MEGA.

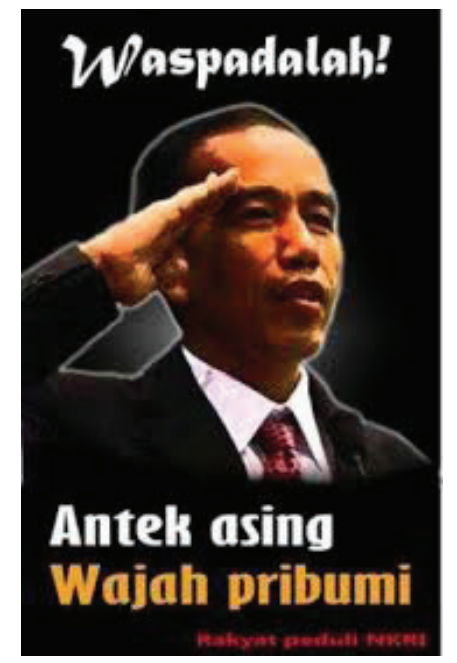

Gambar 13C

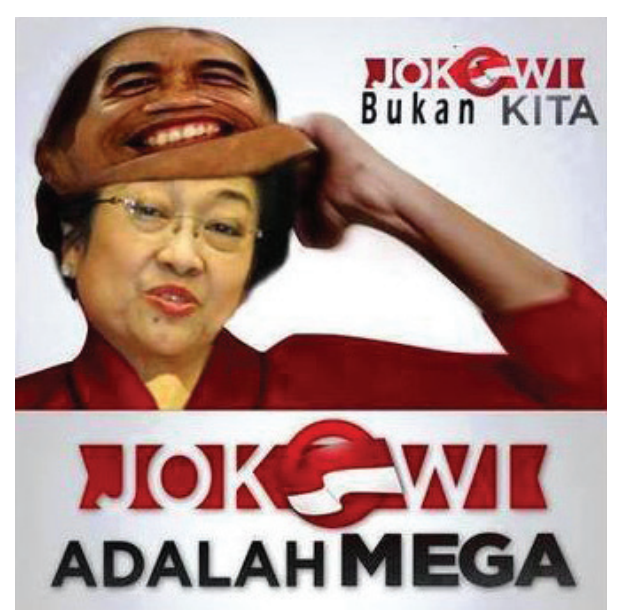

Gambar 13D

\section{SIMPULAN}

Secara garis besar berbagai bentuk penggambaran netizen kepada para pihak terkait dengan kasus dugaan tentang penistaan agama melalui meme-meme yang diproduksi dan direproduksinya mengerucut kepada bentuk kebencian dan pembelaan. Melalui meme yang diproduksi dan direproduksinya, netizen yang kontra terhadap Ahok mempersonifikasi Ahok sebagai penista agama, tidak layak menjadi pemimpin dan berbagai personifikasi kebencian lain. Demikian juga personifikasi terhadap kelompok pro Ahok, Megawati Soekarnoputri, Kapolri Jenderal Polisi Tito Karnavian, dan Presiden Jokowi, sebagai pihak yang tidak luput dari penggambaran negatif penuh kebencian. Sementara itu, meme terhadap Buni Yani memberikan penggambaran yang positif. Dalam hal ini ia menjadi sosok yang dibela.

Meme yang diproduksi dan direproduksi netizen yang pro Ahok memberikan penggambaran berisi pembelaan terhadap Ahok yang juga bertendensi kebencian terhadap kelompok kontra Ahok. Gambaran kebencian juga dilakukan oleh netizen melalui meme yang mereka produksi dan reproduksi, baik terhadap Buni Yani, kelompok kontra Ahok, dan terutama sekali Habib Rizieq. Sementara kepada sosok seperti Kapolri Jenderal Polisi Tito Karnavian, Megawati Soekarnoputri, dan Presiden Jokowi, meme yang diproduksi dan 
direproduksi tidak sebanyak oleh netizen kontra Ahok dan lebih bersifat pembelaan dan dukungan.

\section{KEPUSTAKAAN}

Bbc.com. 2017. Pidato di Kepulauan Seribu dan Hari-hari hingga Ahok Menjadi Tersangka. Retrieved from http://www.bbc.com/ indonesia/indonesia-37996601

Berger, P., \& Luckman, T. 2012. Tafsir Sosial Atas Kenyataan, Risalah Tentang Sosiologi Pengetahuan. Jakarta: LP3ES.

Jurnalweb.com. 2017. Sejarah Asal-Usul Meme Internet. Retrieved from http://www. jurnalweb.com/sejarah-asal-usul-memeinternet/

Mulyana, D. 2003. Ilmu Komunikasi sebagai Pengantar. Jakarta: Remaja Rosdakarya.

Nasrullah, R. 2013. Cybermedia. Yogyakarta: IDEA PRESS.

Nasrullah, R. 2016. Media Sosial: Perspektif Komunikasi, Budaya, dan Sosioteknologi. Bandung: Simbiosa Rekatama Media.

Poloma, M. 2004. Sosiologi Kontemporer. Jakarta: PT Raja Grafindo Persada.

Salim, A. 2006. Teori dan Paradigma Penelitian Sosial. Yogyakarta: Tiara Wacana.

Solopos.com. 2017. "Inilah Pengertian dan Sejarah Singkat Istilah Meme".

Sutrisno, M. dkk. n.d.. Cultural Studies: Tantangan bagi Teori-teori Besar Kebudayaan. Depok: Koekoesan.

Tinarbuko, S. 2003. Semiotika Komunikasi Visual. Yogyakarta: Jalasutra.

Vivian, J. 2008. Teori Komunikasi Massa (Edisi Terjemahan). Jakarta: Prenada Media Group. 